\title{
MUDANÇAS E NOVIDADES
}

O primeiro número de 2015 da revista Tecnologia em Metalurgia, Materiais e Mineração é marcado por mudanças e novidades. Começamos apresentando um artigo de revisão de grande interesse, preparado pela Professora Neusa Alonso- Falleiros. Ele traz uma visão bastante completa do tema "Trincamento induzido por Hidrogênio em Aços Microligados" que, ao mesmo tempo que instrui e informa sobre o assunto, importantíssimo no transporte de gás e óleo, mostra o estado da arte na questão. Artigos de revisão são extremamente relevantes para os leitores da TMM, e agradecemos a colaboração daqueles que, com conhecimento e disposição, nos ajudam a compor o periódico.

Aproveitamos a oportunidade para agradecer à Prof. ${ }^{a}$ Neusa, que agora se aposenta da USP, pelo seu incansável empenho no ensino e desenvolvimento da área de materiais. Ela influenciou fortemente alunos e professores durante anos, não só por seu importante trabalho de pesquisa, mas, em especial, por sua dedicação aos alunos e às atividades de ensino.

A Revista TMM aproveita esta oportunidade para transmitir a ela o agradecimento e os votos de felicidades dos colegas, ex-alunos e colaboradores, e a nossa esperança de que a professora não se afaste completamente da atividade na área.

Depois de um longo período de dedicação intensa à Revista, o Prof. Rodrigo Magnabosco passa a se concentrar mais em suas pesquisas, deixando o cargo de editor-executivo, mas continuando a contribuir como revisor. $O$ corpo editorial agradece pelo excelente trabalho e pela atenção e dedicação à TMM.

Considerando a responsabilidade do trabalho e visando tornar o processo editorial ainda mais ágil e compatível com o amplo escopo da nossa publicação, optou-se por dividir a missão do editor-executivo em áreas. Assim, damos as boas-vindas ao Prof. André Carlos Silva, editor-executivo da área Mineral, à Prof. ${ }^{a}$ Danieli Reis, editora-executiva da área de Materiais e ao Prof. Flávio Beneduce, editor-executivo da área de Metalurgia. Desejamos aos novos editores-executivos muito sucesso e agradecemos o apoio voluntário à Revista, essencial para o nosso êxito.

Ainda no campo das novidades, com objetivo de aumentarmos a abrangência, os autores poderão agora enviar artigos também no idioma espanhol. E, de modo a aperfeiçoarmos ainda mais o nosso processo de avaliação, adotamos o sistema double blind, tornando a avaliação ainda mais imparcial; uma vez que nomes de autores e de revisores não são revelados.

Esperamos que o ano de 2015 traga ainda mais aprimoramentos ao nosso processo editorial, e que possamos oferecer aos nossos leitores novos e interessantes artigos de revisão.

André Luiz Vasconcellos da Costa e Silva

Editor-chefe 